\title{
Review of Mark Honigsbaum (2020). The Pandemic Century-A History of Global Contagion from the Spanish Flu to Covid-19
}

\section{Cambridge, MA: Penguin. 321 pp. ISBN 9780753558287}

\section{Adam Matthews ${ }^{1}$}

Published online: 20 July 2020

(C) Springer Nature Switzerland AG 2020

Keywords Pandemic $\cdot$ Covid-19, virus $\cdot$ History $\cdot$ Episteme, social, postdigital $\cdot$ Knowledge

\section{Introduction}

A dominant narrative of the 2020 Covid-19 pandemic has been that governments and institutions have been 'guided by the science' when making decisions to lockdown countries and regions and then subsequently lift restrictions and return to 'business' as usual. The singular 'science' has been used rhetorically to justify such decisions. Mark Honigsbaum's The Pandemic Century-A History of Global Contagion from the Spanish Flu to Covid-19 (2020) is written as an archaeology of pandemic knowledge from the past 100 years. Honigsbaum's detailed exploration shows that there is anything but one, stable, quantified truth to be found during a pandemic - aka 'the science'.

The archaeological 'dig' of ten pandemics from the last century, unearthing the complex interplay between the natural and the social, could quite conceivably reference Foucault and The Archaeology of Knowledge (Foucault 2002) as a methodological framework. Another of Foucault's works, The Order of Things (Foucault 2007), is also relevant with its focus on biology, economics and linguistics (life, labour and language). In detailing such complexities which involve myriad disruptions of ecological equilibriums with new ways of living and technologies, the 'science' then becomes a reified rhetoric (Lukács 1990). Lukács’ theory of reification mechanically objectifies commodity structure in capitalism, described by Lukács as a 'phantom objectivity'. The ten cases detailed in The Pandemic Century (Honigsbaum 2020) show that in each pandemic, there is never one truth to be found but a complex interplay between - in

Adam Matthews

a.matthews.3@bham.ac.uk

1 University of Birmingham, Birmingham, UK 
Foucault's (2007) words - biology, economics and linguistics. When a phantom objectivity of one objective scientific truth enters the order of things, pandemics exploit epistemological blind spots again and again.

Honigsbaum surveys with biological detail the genealogy and history of influenza, the plague, Parrot Fever, Legionnaires Disease, Aids, SARS, Ebola, Zika and Covid19. This history is foregrounded by the sociological perspective of how outbreaks first come about and then how they are dealt with politically and economically by governments and media - the economics and linguistics. The common theme across all accounts is that ecological equilibriums are disturbed, resulting in mutation of viruses taking humanity by surprise each time. In the words, again of Foucault (2007), each episteme has accepted knowledge and practice which is exploited when pathogens do not conform to what has gone before. The book's ten cases show how, what worked before, being applied to a new unique scenario and environment, often sets epidemiology, parasitology, zoology, molecular biology, media, governments and others on the wrong course of investigation under the influence of the current episteme. As viruses mutate in the face of ecological changes, so do scientific paradigms as outlined by Kuhn (1996).

Wars, urban development, pet parrots, luxury air-conditioned hotels and offices, an increasingly more globalized world of international travel and market developments, have disrupted ecologies for the past 100 years. This review responds to a call for us all to look to what the 2020 pandemic means in this social experiment we are living through (Jandrić 2020). In responding to this call, I have already made my own links to theoretical concepts and frameworks which Honigsbaum does not make (Foucault, Lukács and Kuhn). In the following sections, I review The Pandemic Century (Honigsbaum 2020) from these perspectives and in the conclusion make further links to scholarly work which can see these histories through the lens of postdigital science and education and beyond.

\section{Coronaviruses-SARS and Covid-19}

Chapter 8, 'SARS: "Super Spreader", is a pertinent place to start in that SARS has many similarities to Covid-19; the most obvious being that they are both coronaviruses. Honigsbaum concludes the chapter on the SARS pandemic of 2002 with, when read in 2020, a chilling cautionary tale:

At a post-mortem at the Royal Society in London, Roy Anderson, the rector of Imperial College and an internationally renowned epidemiologist, was similarly cautious. Although the WHO's handling of SARS had restored faith in the UN, the world has also been 'very lucky,' he wrote. It was only thanks to the low transmissibility of SARS and the fact that China and other Asian countries had been able to introduce 'fairly draconian' public health measures, such as home isolations and mass quarantines, that disaster had been averted. He predicted such measures would have met with greater resistance in North America, where people tended to be more litigious, and to a lesser extent in Western Europe. The persistence of SARS in animal reservoirs meant that further outbreaks were inevitable. In the meantime, the real global threat came from the emergence of 
an antigenically novel influenza virus. 'One of the major dangers arising from the effective control of SARS is complacency,' Anderson concluded. 'Sentiments of the type, "we have been successful once - we will be again," may be far from the truth.' (Honigsbaum 2020: 194)

The SARS story begins with the economic manufacturing boom in Hong Kong's nearby Guangdong province in mainland China. An increasing population required industrial-scale poultry farms as well as home-bred poultry and pig farms, often situated near big factories, to feed the growing population. The upwardly mobile city also imported rare animals as delicacies into fine dining restaurants. This all contributed to ecological changes to the city and wider region. Coronavirus had up until then been of little interest to scientists and described by the author as the 'Cinderella of the microbial world' (Honigsbaum 2020: 185). Cinderella made it to the worldwide stage however as a deadly disease which spread to 30 countries, resulting in 916 deaths.

As SARS broke out, it was clouded with its own assumptions as it was originally investigated as bird flu which had broken out in the late 1990s and had resulted in 18 human infections and 6 deaths as well as the culling of 1.5 million chickens. Epidemiologists' detective work traced the disease to the 9th floor of a Hong Kong hotel and a housing estate, from where it boarded planes around the world. SARS became known as the jet set disease, spread by international travellers in an ever more globalized world. Like many of the other cases in the book, hysteria took hold with misinformation, conspiracy theory and pure lack of understanding, all under the backdrop of the 9/ 11 terror attacks and the Iraq war. SARS travelled by bus from Guangdong to Hong Kong and then on commercial flights to Vietnam, Singapore, Thailand and Canada. It is now thought that civet cats sold in wet markets were the source. Demand for exotic sources of protein, urban overcrowding, international travel and the interconnected market economy all came together to provide the perfect environment for the virus to flourish and spread.

The alerts about the first cases of Covid-19 in December 2019 came from the trawling of websites and social media, a method that has become standard in tracing diseases. The details of the pneumonia cases led expert medical epidemiologist Dr. Marjorie Pollack to a feeling of déjà vu after working on SARS. The feeling of déjà vu is something readers of The Pandemic Century (Honigsbaum 2020) will feel when reading each case as well as living through the first half of 2020 (Watkins et al. 2020; Apuzzo et al. 2020).

The déjà vu continues when reading chapters eight and nine on the Ebola outbreak in Africa in 2013 and Zika virus in Brazil in 2015. Honigsbaum traces a child in Guinea coming into contact with bats and displaying severe symptoms which at the time were diagnosed as malaria or Lassa fever, common in the area before 2013. While unidentified, Ebola spread through a network of infections from family through health workers to funeral guests to large parts of Africa. The story was familiar, treating symptoms of a new unknown disease with what had worked before. Another familiar story was the disinformation and conspiracy theory which was as infectious as the disease itself, spreading and causing hysteria and panic worldwide. The author concludes that the detailed detective-like epidemiological investigation with the findings of ecological disruption of migratory fruit bats carrying the disease as they always had done, but clearing of forests for cultivation of palm oil drove bats closer to humans, infecting a child which sparked off the familiar domino effect of the spread. 
Zika virus hit Brazil in 2015. Again, the virus was little known and was treated as an arbovirus, transmitted by mosquitos, yellow fever, chikungunya or dengue. Zika virus has flu-like symptoms, red eye and a rash but also results in microcephaly (a smaller than normal head) in newborn babies transmitted by the mother during pregnancy. The virus made it to Brazil and beyond (50 countries in the Americas) through mosquitos from international commerce. Travelling mosquitos found perfect homes to thrivepoor sanitation in the favelas and limited access to piped water.

The first cases of Covid-19 in 2019 were in and around Wuhan's Huanan Seafood Wholesale Market, trading a range of wild animals. Patient zero fell ill on December 1st potentially contracting the virus 14 days before and the virus began it's worldwide journey. While confident predictions and hypothesis were made and challenged, rumours spread as did the new Covid-19 virus itself, described by Honigsbaum as 'China's Chernobyl moment' (2020: 262). Three weeks into January, Wuhan and 10 other cities were in lockdown but it was too late and 5 million people had left Wuhan, many travelling overseas with a new virus for which nobody had immunity.

Without a vaccine, the only way to preserve public health is to isolate and quarantine people which due to liberal politics in the West, especially the UK and USA, is difficult to do politically. It appears that such delays and concern over political messaging and 'freedoms' has increased infection rates. Readers of this review will not need further detail about Covid-19 as it plays out in front of our eyes on 24-hour news and social media.

\section{Wars, Urban Development, Parrots and Air Conditioning}

Déjà vu hits again when reading earlier chapters on previous pandemics from the past 100 years. Camp Devens in the small town of Ayer, Massachusetts, is described as the place where troops came together to train and prepare for World War I. Soldiers came from rural and urban environments sparked an ecological imbalance to infect one-third of the world's population with a new strain of influenza-Spanish Flu. A second wave bought the virus back to the USA infecting New York and Philadelphia with politicians ordering unprecedented quarantines and lockdowns. Debates over use of and how to make home-made masks and mass panics broke out across the country. Latest estimates are at 100 million deaths worldwide.

In 1924, the plague made a return to Los Angeles, California, breaking out in a Mexican community who had rebuilt the modern city and worked hard to keep the city running and developing. A fear of political and economic damage resulted in the Health Commissioner denying the evidence. Quarantine and lockdown in Los Angeles took hold and it became clear that what had been denied as not possible in the city of the future was a reality - a breakout of the disease from the dark ages - the plague. This threatened booming tourism, real estate sales and an ambition to make the LA port the largest commercial harbour in the USA. Public officials and local newspapers continued to call the outbreak anything but the plague, but newspapers on the West coast reported black death in an economic move to boost circulations and business advantage. The solution was demolishing the neighbourhoods in which the outbreak emerged and slaughtering squirrels in huge numbers. Today, there is still no conclusive evidence of the cause. The 
development and ecological disruption of the polished city of the future is now thought to have heavily contributed to the outbreak.

The 1929 outbreak of Great Parrot Fever had a particularly social and cultural element - the human-like, speaking and chirping parrot. O'Sullivan (2020) describes the contradictory relationship between human and non-human animals in the context of the 2020 pandemic from the entertaining distraction of funny YouTube videos to the blame for the source of Covid-19 in wet markets where live animals are traded through to animal testing to provide a vaccine. The end of 1929 was pre-Monty Python and their famous dead parrot sketch, but it was at the height of parrots as household pets and entertainment, described as the FM radio of the day. Parrots provided background noise, companionship and 'conversation' for US homes. Post-Wall Street crash, selling parrots became an industry and New York was a hub for the sale of fashionable birds. The popular cultural comedy position of the parrot was a newspaper headline writers' dream to spread hysteria but also for chuckling and dismissal by expert physicians in the face of a new disease outbreak.

Again, disrupting an ecology resulted in pandemic when parrots and other birds were removed from their natural environment. 50,000 parrots, parakeets and lovebirds and 500,000 canaries were imported into the USA for their ' ... buffoonish behaviour, and their talent for hanging upside down or dancing on their owners' shoulders were a source of endless amusement for children and an entertainment for house guests' (Honigsbaum 2020: 71). The virus that the birds carried was mild in their own habitat, but when transported, and the birds stressed resulted in infection and subsequently pandemic. By 1930, 800 cases were recorded worldwide with a fatality rate of $15 \%$. The Bird Dealers Association of America denied the claims and put the blame on the media for inventing a story - the association stood to lose $\$ 5$ million annually. With an import ban in place, amateur breeders set up business. Psittacosis was found in Australian birds and had been latent for centuries but the desire to have a talking bird entertaining the family resulted in pandemic.

In 1976, scientific and public opinion moved towards a hegemonic discourse of an all-knowing science. Vaccination and treatment with antibiotics were widespread and there was a feeling of rational scientific research had 'beaten' all pandemic threats. That was until what turned out to be Legionnaires disease bamboozled the Director of the US Center for Disease Control (CDC): 'The outbreak... has represented a number of unusual and complex features... It has run counter to our expectations that contemporary science is infallible and can solve all the problems that we confront.' (Honigsbaum 2020: 104). Termed the Philly Killer and making the front cover of Time Magazine in 1978 (see Fig. 1), the outbreak originated from the plush Philadelphia Bellevue Hotel after an annual meeting of the American Legion. Many of the party fell ill and died, leading to an investigation which was at first treated under the then current paradigmatic way of thinking after a symptomatically similar outbreak of swine flu. The case became a mystery as the staff were not affected, but many guests, passers-by and air conditioning engineers were.

The two chapters covering what was to become Legionnaires disease, named after the American Legion members who died, shows the complex needle in haystack-type investigations which scientists undertake to get to the bottom of such outbreaks. Epidemiologists set out on asking who, where, when, how and what, to understand the biological make-up of new diseases. The how and what of the American Legion 


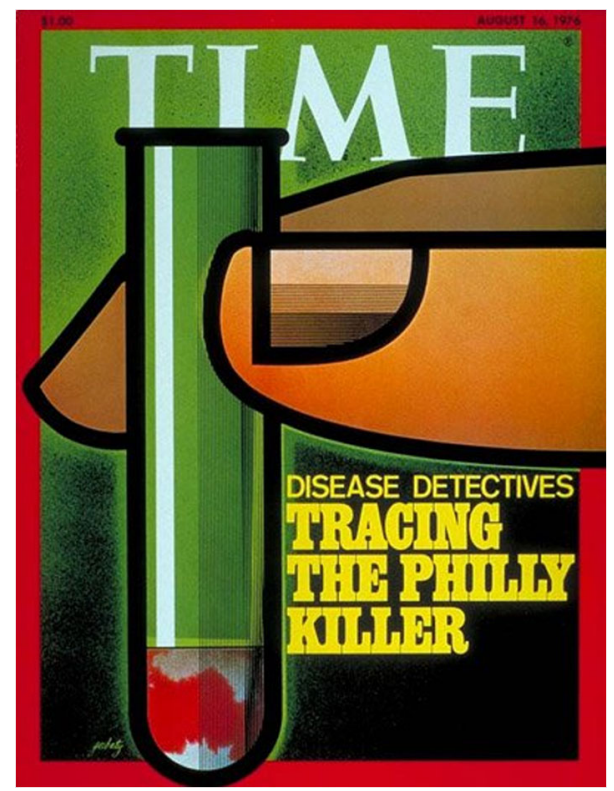

Fig. 1 Time Magazine cover August 16, 1976 (in Rothman (2015)

outbreak at the Bellevue was a long and detailed search starting from the hotel lobby with many dead ends and unsuccessful hunches. A now familiar tale, alongside the biological investigation was the panic, hysteria and hubris including the Time Magazine cover, political and newspaper blame for the $\mathrm{CDC}$, theories of terrorist distribution of poison by anti-war movements leading to paranoia from the right and left of the political spectrum. Under the backdrop of Cold War nuclear power and moral panic, the wild speculation even led to a Bob Dylan song called Legionnaires disease.

While all of the discourse was playing out in 1970s America, detailed investigations were being carried out. The cause of the new disease was cooling towers, part of air conditioning systems, which if not maintained, contaminated water, then aerosolised into droplets which can then get into a person's lungs through air conditioning and showers. The bacteria existed for centuries in natural environments but in higher temperatures in cooling towers result in a niche where it thrives - a classic example of how new technologies which make life easier for some can result in unknown and unintended consequences. All previous investigations were based on the assumption that in 1976, contemporary science was infallible and can solve all the problems that we confront. It took a new way of approaching the problem by Joseph McDade (Gordon 2016), discovering a bacterium that scientists had not found before, to find a cause for Legionnaires disease.

The subsequent chapters trace in similar style the detailed scientific, cultural and societal aspects of both the investigations and the possible causes of various pandemics. AIDS killed 40 million people, and is different to many of the other pandemics in that modern science and technology was ready for its outbreak and was able to relatively quickly identify the virus. What was harder to get under control was the moral panic with which society faced with the 'gay plague' (Honigsbaum 2020: 138). The panic and stigma of the early 1980s is exemplified by media and politicians' descriptions as 
'God's judgement', 'voodoo', a comet from outer space or a bioweapon. In tracing the potential source of AIDS, a familiar story develops. Honigsbaum describes ecological disruption amplifying the mutation and spread of a virus which had existed in its natural environment for centuries. The amplifying effect is hypothesised as the reuse of inadequately sterilised hypodermic needles and syringes in attempting to treat other diseases. Secondly, colonisation in the Congo resulted in an influx of workers to build new railway and road infrastructure. These workforces had gender imbalances of four males to one female resulting in increased sexual activity and sex work which amplified the spread.

\section{Conclusion}

From a postdigital perspective, the ten cases detailed by Honigsbaum in The Pandemic Century (2020) show how digital and wider technologies are not separate from the natural and social world. New technologies enter natural and social ecologies in complex and often unintended ways. Air conditioning technology and urban development projects are just two of the examples whereby disruption to an ecological equilibrium resulted in unknown or new pathogens emerging to mutate, catching humanities' epistemological limits off guard. Further technological developments such as global air travel means that viruses can spread much more quickly turning epidemics into pandemics within 72 hours and media technology spreading the discursive news of a virus at the push of a button.

Returning to Foucault's Order of Things (2007) (biology, economics and linguistics), we can describe the pandemic century as biological change and disruption often driven by economic advancement and neoliberal policy fuelled by 24-hour news and social media. The linguistic aspect plays out in (old and new, one to many and social) media and everyday discourse. Panic, hysteria and hubris are keys to the sociological analysis of each case in the book. The at the time unknown Legionnaires disease made the front cover of Time Magazine as the 'Philly Killer' (see Fig. 1), and panic dominated political and news media. Similarly, AIDS was labelled as 'the gay disease' sent from God to punish. Lies, bullshit and fake news (MacKenzie and Bhatt 2020) hold a complexity which belies convenient soundbites in that there is not a simple true and false dichotomy with the truth to be found. This holds similarities with scientific discourse claiming 'victory' over nature.

Ecological disruption then is not just biological but economic and linguistic. These complex ecologies are far from stable or holding one grand narrative or truth. A new virus is often unknown or under researched at the outbreak and the volume of information produced by traditional and new media enter into these ecologies. Wuhan Doctor Li Wenliang used social media to warn colleagues to wear protective equipment as to not catch Covid-19 in 2020 but was warned by the Chinese government to stop making false comments which was disrupting the social order (BBC 2020). Li Wenliang later died of the virus, aged 34. His words and those reporting on them entered the social ecology of the virus.

A war against the virus is discursively constructed, as one objective truth to be found and 'defeated' with the rhetoric of war used by governments to create another binary of you are either with us or against us in our battle (Wagener 2020). In the second half of 
2020 as we emerge from the initial spread of Covid-19, we can learn lessons from the previous 9 pandemics documented in the The Pandemic Century. Ecologies of biology, economics and linguistics do not sit in siloed neatly partitioned environments but as complex networks of pathogen mutilation as well as social and cultural human behaviour. Governments, organisations and individuals are faced with complex, wicked problems (Rittel and Webber 1973) that go beyond a phantom objectivity of 'the science' with tame cause and effect.

Fuller (2020) highlights the increased media gaze on Covid-19 and its ecological impact. Moreover, Fuller in a post-truth environment states that there are those that want to claim victory and return to 'business' as usual and there are those who want to play a new game all together and use 2020 as year zero in how we live and work. Fuller offers two options ahead of us, which in the post Covid-19 world appear particularly pertinent. One option is to continue with technological developments in a proactionary, transhuman manner, and the other option is to pull back to a precautionary posthuman position (Fuller 2018) with more humble ambitions for the ecologies which include the human and non-human (Fuller and Lipińska 2014). Fuller's Humanism 2.0 offers a political framework with which to move forward. The posthuman 'down wingers' and transhuman 'up wingers' displace the traditional left vs. right political axis. The questions then, which The Pandemic Century (Honigsbaum 2020) illustrates is whether to take a posthuman perspective and pull back from technological and human development and reduce ecological disruption and work with the natural environment as equals or to push on unabated with technological developments to go beyond what has been done already to 'fix' ourselves and the planet, including new viral outbreaks. What is clear is that ecologies are constantly disrupted and the human is deeply embedded and part of those ecologies.

\section{References}

Apuzzo, M., Gebrekidan, S., \& Kirkpatrick, D. (2020). How the world missed Covid-19's silent spread. The New York Times, 27 June. https://www.nytimes.com/2020/06/27/world/europe/coronavirus-spreadasymptomatic.html. Accessed 5 July 2020.

BBC. (2020). Coronavirus kills Chinese whistleblower doctor. BBC News, 7 February. https://www.bbc. com/news/world-asia-china-51403795. Accessed 5 July 2020.

Foucault, M. (2002). Archaeology of knowledge. London and New York: Routledge.

Foucault, M. (2007). The order of things: An archaeology of the human sciences. London: Routledge.

Fuller, S. (2018). The posthuman and the transhuman as alternative mappings of the space of political possibility. Journal of Posthuman Studies, 1(2), 151-165. https://doi.org/10.5325/jpoststud.1.2.0151.

Fuller, S. (2020). A post-truth proactionary look at the pandemic. Postdigital Science and Education. https://doi.org/10.1007/s42438-020-00124-5.

Fuller, S., \& Lipińska, V. (2014). The proactionary imperative: A foundation for transhumanism. Basingstoke: Palgrave Macmillan.

Gordon, E. (2016). 40 years later, scientist who first discovered Legionnaires' disease is still learning lessons. WHYY, 28 July. https://whyy.org/articles/40-years-later-scientist-who-first-discovered-legionnairesdisease-is-still-learning-lessons/. Accessed 5 July 2020.

Honigsbaum, M. (2020). The pandemic century: A history of global contagion from the Spanish flu to Covid19. Cambridge, MA: Penguin.

Jandrić, P. (2020). Postdigital research in the time of Covid-19. Postdigital Science and Education, 2(2), 233238. https://doi.org/10.1007/s42438-020-00113-8.

Kuhn, T. S. (1996). The structure of scientific revolutions (3rd ed.). Chicago, IL: University of Chicago Press. Lukács, G. (1990). History and class consciousness: Studies in Marxist dialectics. London: Merlin. 
MacKenzie, A., \& Bhatt, I. (2020). Lies, bullshit and fake news: Some epistemological concerns. Postdigital Science and Education, 2(1), 9-13. https://doi.org/10.1007/s42438-018-0025-4.

O'Sullivan, V. (2020). Non-human animal trauma during the pandemic. Postdigital Science and Education. https://doi.org/10.1007/s42438-020-00143-2.

Rittel, H., \& Webber, M. (1973). Dilemas in a general theory of planning. Policy Sciences, 4, 155-169.

Rothman, L. (2015). How Legionnaires' disease got its name. Time, 12 August. https://time.com/3994453 /legionnaires-disease-name-history-1976/. Accessed 8 July 2020.

Wagener, A. (2020). Crushed by the wheels of industry: War, heroes, and domestic recolonization in the time of Covid-19. Postdigital Science and Education. https://doi.org/10.1007/s42438-020-00140-5.

Watkins, D., Holder, J., Glanz, J., Cai, W., Carey, B., \& White, J. (2020). How the virus won. The New York Times, 25 June. https:/www.nytimes.com/interactive/2020/us/coronavirus-spread.html. Accessed 5 July 2020. 